\title{
RESILIENCY OF SMALL-SCALE COMMON CARP (Cyprinus carpio) FARMERS IN WEST PAGADEN RURAL AREA OF SUBANG - WEST JAVA (Daya Lenting Pembudidaya Ikan Mas (Cyprinus carpio) Skala Kecil di Perdesaan Kecamatan Pagaden Barat Subang - Jawa Barat)
}

\author{
Carolina* $^{*}$ \\ Pusat Pengembangan Teknologi Tepat Guna, Lembaga Ilmu Pengetahuan Indonesia \\ Jalan KS Tubun No 5. Subang 41214
}

*Korespondensi. No Tel: 0260 412878. Fax 0260 411239. Email: carolina.4q@gmail.com.

Diterima: 2 November 2014

Disetujui: 28 Februari 2015

\begin{abstract}
Since early 1980s, freshwater fish farming was introduced as an economic activity to the rural community in Subang, West Java Province. Until presently, 5\% of the population participate on it, specifically as common carp (Cyprinus carpio) cultivators in freshwater ponds ecosystem. The economic gain from the carp farming triggers vast development indicated by significant landscape conversion from rice fields to fish ponds. Environmental limitation does not seem to become their major concern, because good yields which means good income is their main driving factor to extend and intensify common carp aquaculture. Recognizing the important role of small scale fish farms in West Java common carp production system, we explore their resiliency in confronting challenges encountered in managing the freshwater ecosystem. Utilizing participatory observation and interview, we explore their socio-ecological resilience from the perception of human and nature interaction. The study area is Pagaden Sub District in Subang West Java. Descriptive analysis is used to articulate the phenomenon enfolded in a socio-ecological framework of thinking. It can be concluded that high dependency to the aquaculture activity, has reached a situation in which ecologically sound technology should be introduced. Included in a scheme of technical assistance which specifically designed to meet the need and in harmony with the socio-cultural characters of small-scale fish farmers, the technology introduction should be carried out to spur the sustainable aquaculture in Subang West Java. This should be a proposed agenda for the local government in support to aquaculture sustainable development.
\end{abstract}

Keywords: aquaculture ecosystem, common carp, ecology, environmental management, resiliency, rural community.

\begin{abstract}
Abstrak
Sejak awal tahun 1980, budidaya ikan air tawar diperkenalkan sebagai kegiatan ekonomi masyarakat desa di wilayah Subang, Propinsi Jawa Barat. Dewasa ini, sekitar 5\% populasi terlibat di kegiatan tersebut, terutama sebagai pembudidaya ikan mas (Cyprinus carpio) di ekosistem kolam air tawar. Pendapatan yang diperoleh dari kegiatan budidaya ikan mas telah memicu terjadinya percepatan laju pembangunan yaitu dengan adanya perubahan lansekap dari petak-petak sawah menjadi kolam-kolam ikan. Keterbatasan lingkungan tampaknya tidak dipertimbangkan, karena hasil panen yang tinggi atau keuntungan usaha menjadi tujuan pokok perluasan atau pun intensifikasi kegiatan budidaya ikan mas. Mengingat peran penting pembudidaya ikan skala kecil di rantai produksi ikan mas di Jawa Barat, kami melakukan kajian terhadap daya lenting mereka dalam menghadapi tantangan mengelola ekosistem budidaya ikan air tawar. Dengan memanfaatkan metoda pengamatan-partisipatif dan wawancara mendalam, data dan informasi dari para pelaku budidaya ikan mas skala kecil di Kecamatan Pagaden Kabupaten Subang Jawa Barat ditelusur. Analisis data dilakukan secara deskriptif untuk memberikan ruang artikulatif dalam mengurai fenomena lapangan yang dirangkum dalam kerangka pikir sosio-ekologi. Dapat disimpulkan bahwa meskipun mereka memiliki kearifan lokal tersendiri dalam membudidayakan ikan mas di kolam air tawar, ketergantungan yang tinggi pada kegiatan akuakultur ikan mas, telah sampai pada situasi diperlukannya pengenalan teknologi budidaya yang ramah lingkungan. Pengenalan teknologi tersebut seyogyanya disertai strategi pendampingan yang sesuai dengan kebutuhan dan karakter sosial-budaya para pembudidaya ikan mas skala kecil. Hal ini perlu dijadikan agenda pemerintah daerah untuk diterapkan demi keberlanjutan pengelolaan ekosistem akuakultur di Subang - Jawa Barat.
\end{abstract}

Kata kunci: daya lenting, ekologi, ekosistem akuakultur, ikan mas, masyarakat desa, pengelolaan lingkungan. 


\section{INTRODUCTION}

Known as an agricultural country, Indonesia also considers aquaculture as potential economic resource. In 2012, we are one of 10 highest fishproducer countries in the world, ranked $4^{\text {th }}$ following China, India and Vietnam (Anonymous, 2014 ${ }^{\mathrm{a}}$. Aquaculture is also Indonesia's development priority due to its considerable economic and social contribution. Of several important species being cultured, one of which is common carp or Cyprinus carpio which is popularly cultured in West Java ponds in floating cage net ecosystem. There are 295.357 households engaged in carp aquaculture management system in the province, producing approximately 67.071 Tonnes in 2012, valued at Rp. 1.006 million (Anonymous, 2014 ${ }^{\mathrm{c}}$ ). Of those, 67,7 \% households fall into the category of small scale. It is certainly not an economic activity to overlook for Indonesia, as figured in 2012, aquaculture community capacity building means giving a chance to approximately 1.1 million families managing Rp. 3,199 trillions worth common carps production (Anonymous, $2014^{\mathrm{C}}$ ). A significant portion of it contributed by rural small-scale aquaculture communities. The aquaculture activity serves as family income generator, fish protein provider, as well as rural job creator. Their important role to food security alone should be the rationale to promote the system to become a sustainable economic activity providing prosperity for the people engaged in. Being small in scale, their existence is often disregarded even though in global picture, contribution of small and medium sized farms is majority (Lazard et al, 2010) thus neglecting specificity of various characters embedded on how they manage own resources is inconsiderable. Richness of characters in technology implemented, management strategy and environmental situation should be appropriately appreciated (Ratner and Allison, 2012, Kittinger et $a l, 2013$ ) in order to avoid misconception that could lead to generation of incompatible strategy on aquaculture development.

As direct resource of livelihood, general perspective believed among small-scale fish farmers in West Pagaden - Subang District of West Java is to dedicate their energy to obtain high profit from carp production aquaculture system. An acceptable perspective, as they are part of common carp production system in the region. The small farmers supply fingerlings to bigger industry of carp culture in floating cage net community in Jatiluhur and Cirata Reservoirs. Therefore preparation of good quality of brood stock, feeding techniques, water and environmental management are all reflected merely to increase the yields
(Hartono and Nasution, 2006). In reference to productivity, caution is aimed to the utilization of feed for it is the most significant input of organic materials to the water body such as Phosphorus and Nitrogen (Panjaitan, 2009; Rasidi and Prihadi, 2009; Rahmani et al, 2011; Riani et al, 2014). Forewarning by way of research results on implementation of aquaculture management technology are well publicized, especially due to the real life cases found in lake and reservoirs such as Toba, Jatiluhur Dam and Cirata Dam where highly intensive common carp culture are implemented.

Learning from those cases, small-scale aquaculture activities are also bound to rules of ecosystem management. Being small in scale, the existence of fish farmers tend to be left unnoticed. Consideration is acquired only through the yields they produce. Not much attention is dedicated to the fact that they do have to confront many challenges in managing their aquaculture ecosystem. As found in fish farmers in lake and reservoirs, small-scale fish farmers in Subang area also have to put up with pressure to gain high income. It is resulted as a general conduct to increase productivity by providing higher quantity of feed in expectation to shorten production cycle. Their simple logic is more input for higher output (Carolina, 2010 ${ }^{\mathrm{b}}$ ). Although accurate data on declination of water quality and or eutrophicationinfluencing environmental factors to fish cultivation performance - are not available, the tendency of productivity decrease has been experienced over time. This unfavorable situation will eventually take the fish farmers to difficult circumstances, pressurize the ecosystem beyond its carrying capacity in order to get high economic return.

From the ecological point of view, small-scale fishponds differ from floating cage net system in lake and reservoirs. The ponds are individually constructed, so that effect of farmers management techniques is not directly experienced by their neighboring ponds. However, ecological failure as occurred in Saguling (Riani et al, 2014), and Cirata Dam (Rasidi and Prihadi, 2005) in which the high quantity of pollutants leads to mass fish mortality are unexpected calamity should be avoided. Threat to sustainability as such is not affordable for the small-scale fish farmers. To prevent that from occurring, we must have the knowledge of their socio-ecological reliance, as it indicates how well they can cope with difficulties in managing their important natural resources i.e. fish ponds ecosystem. It is important to understand their resilience because it implies the ability to absorb disturbance and reorganize while undergoing change so as to retain the function through which 
we could indirectly assess the potency of achieving sustainability (Walker et al, 2004; Folke, 2006).

In reference to their role as important actor to food security, it is indisputably that sustainability of small-scale common carp aquaculture activities should be in our concern. In order to assess the plausibility of achieving it, acquiring knowledge of socio-ecological resiliency of the common carp farmers community becomes important. Their strategy to deal with economic and ecological challenges in aquaculture ecosystem management should become basic consideration for those who are responsible in creating supportive strategy for them to pursue sustainable aquaculture development.

\section{EXPERIMENTAL METHOD}

We design the work as a descriptive research to elaborate aquaculture ecosystem management by small-scale common carp farmers in Pagaden Area of Subang - West Java. Our framework of thinking is constructed in reference of the fact that the smallscale fish farming system is an important part of common carp production system in the region. Subang Area is an important producer of common carps (C. carpio) fingerlings. Therefore our focus is directed towards carp culture management producing fish seed for floating cage net aquaculture system. There is no formal standard for determining the area of land in the category of small scale fish ponds. However, in this study, we define "small scale" for ponds area ranges from 1000 to $2800 \mathrm{~m}^{2}$. Those fall in this category could be considered vulnerable, referred to the fact that they are characterized by limited capital, limited access to technology and limited access to the market, and these characters are found in small scale aquaculture activities in many countries (Lazard et al, 2010; Anonymous, 2013).

This research finds reference in primary and secondary data. Twenty two smallholders, or approximately $10 \%$ of the whole smallholders population in the study area, are selected randomly as samples representing small scale aquaculture common carp farmers in Pagaden Sub District in Subang - West Java (Figure 1). The area where first freshwater fish culture were applied in 1980s. Quantitative data were collected in SeptemberOctober 2011, whereas qualitative data and information were obtained through series of group discussion, participatory observation and interviews to 22 small holders in the study area until May 2012. Descriptive exploration is used to articulate the phenomenon enfolded in a socio-ecological framework of thinking based on the pattern of the system construction and human interaction with the environment (Marten, 2001). The discussion throughout this paper is aimed to explain both, resilience and adaptation strategy performed by the fish farmers. It is expected that from the description we will be able to obtain reflection on how to attain sustainable development capacity.

\section{RESULTS AND DISCUSSION}

\section{General situation of the Study Area}

Subang is one of 17 regencies in West Java Province of Indonesia. Situated on northern part of the province, Subang covers an area of 2,051.76 square kilometer, an area resided by 1,465,157 in 2010 and a population density of 710 people per

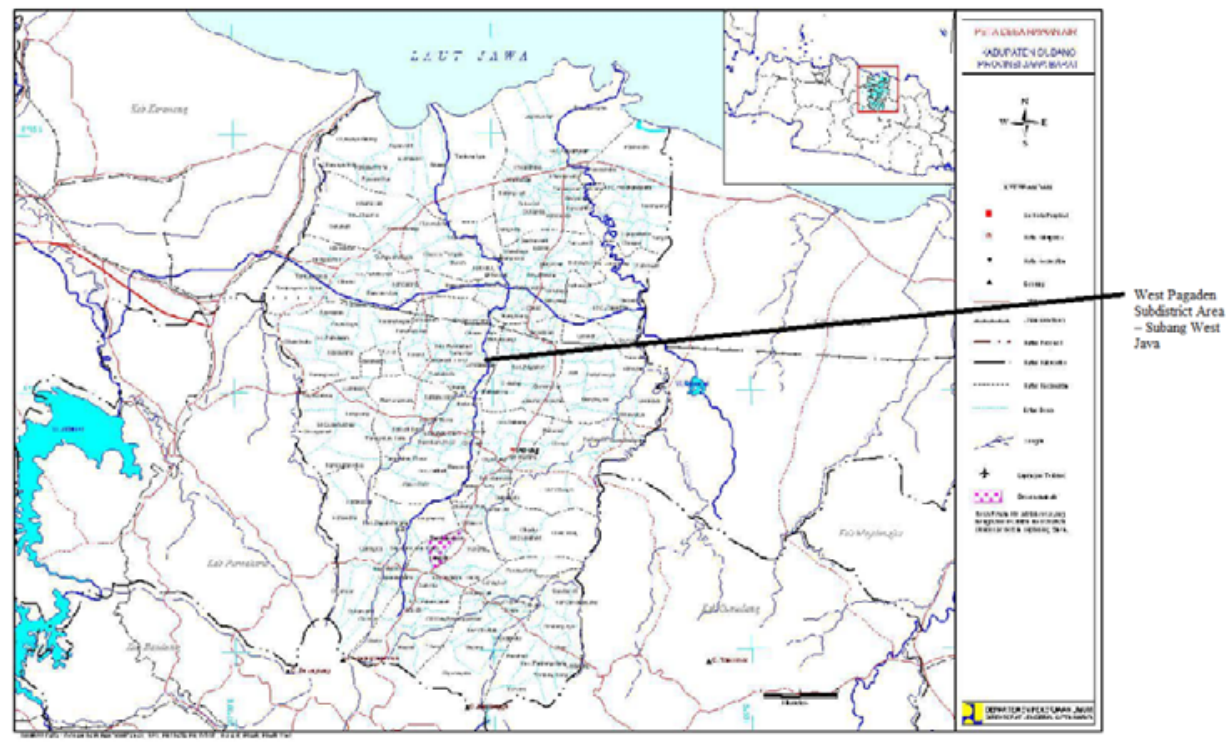

Figure 1. Approximate location of West Pagaden Sub District in Subang - West Java (Source : Anonymous, $2014^{\mathrm{b}}$ ). 
square kilometer. Mainly depend on agriculture, $5 \%$ of the population engaged on fishery sector, and $5.7 \%$ of the area is utilized to support fish culture activities (Anonymous, 2012). In spite of the fact that Subang is known as common carps fingerling supplier for floating cage net culture fish farming system in 2 large reservoirs i.e. Jatiluhur and Cirata in West Java, its strategic potency remains underestimated. In reality, landscape changes as an expression of "common carp aquaculture rush" do occur and easily recognized. Up to present day, attention to the fish farmers who are the prime actors who ensure the sustainability of the freshwater aquaculture systems still need to be enhanced.

Administratively, Subang District is divided into 30 sub districts. Pagaden Barat or West Pagaden is one of the highest producers of common carp fingerlings. Located in the center of Subang area, the Sub District has 38,205 residents living in $48.25 \mathrm{~km}^{2}$. As many other agricultural area, most of the population depend on agricultural activity i.e. rice fields and fish farming.

Economic gain is indeed the main motivating factor for fish cultivators to transform their rice fields to become fishponds which resulted in significant environmental change (Carolina, $\left.2010^{\mathrm{b}}\right)$.Started as a simple tradition, the non commercial home garden fishponds are now transformed to intensively managed commercial ponds which are purposely constructed in rice fields area. Without any measure, in the long run, this change will cause irreversible ecological damage none of us would expect.

\section{Aquaculture Management : The Small Farmers Adaptation Strategies}

An aquaculture activity will sustain if its ecological balance is maintained. It means that its supporting ecosystems have good resilience to function in their niche. Aquaculture ecosystem is formed by several environmental factors, such as soil and water that help fishes survive in ponds as their habitat. There are 4 aspects in small scale rural aquaculture considered as significant problems for freshwater fish farmers in Subang affecting the fishponds productivity which at the end determining income they could gain (Carolina, 2010; ; Novianti, 2010). Those aspects are decreasing quality of broodstocks, quality and quantity of water, price and quality of fish feed, and pest and diseases.

In the last few years, farmers have been having difficulties in finding quality broodstocks. This situation resulted from a decade long problems of Koi Herpes Virus infestation to common carps that makes culturing carps in running water becomes difficult. Running water is a special fish culture system applied by Subang farmers community in hill sides. Since heavy infestation of the virus in 2002, the condition has not been revived yet (Carolina and Aji, 2008). Only those farmers with strong capital can start revitalize their activity, and that is only handful of them. This situation has left fish farmers to a difficult situation of not having enough good quality broodstocks.

Low quality broodstocks create problems for fish farmers who produce fry carps. Fish farmers who own and managed small ponds tend to choose fry production as their activity, which only take 10 to 12 days working cycle starting from pond preparation and fish spawning. Those who practice this short period of activity eventually emptied their ponds 3 times a months, and it also means 3 times filling in water. When many farmers do this consecutively in many different area, it causes significant volume of irrigation water flow for rice fields. This is how conflicts over water occur unavoidably. Water availability starts to become a problem. Although there is always somebody from the community who are assigned as irrigationwater-manager or "mitra cai" , farmers usually call upon other respected figures to lead the negotiation.

On the other hands, they begin to experience water quality problems. Water quality preservation is closely related to soil treatments that farmers apply to their ponds. At the early stage of pond preparation, the soil is plowed and flattened to make the floor free of mud that usually contains deposit of residual feed. It continues at the feeding stage all through the rearing period. Why is feeding considered affecting soil in the pond? It is true that feed provides fish with nutrition, but the feeding technique itself never guarantees the feed is $100 \%$ consumed. There is always feed waste that can either make water fertile or accumulate organic substance at the bottom of the ponds. This will create disadvantageous situation for cultured fishes, and it can slower the growth. They are fully aware with this situation, and cope with it by leaving the sediment dry for a certain period of time before reusing the pond for next rearing period.

Compounded with ever increasing price of fish feed, the fish farmers decide to confront the situation by reducing the need of working capital by only producing carp larvae and 3-5 cm length fingerlings. Those two stages do not require much fish feed as those activity to breed carp for 3 months consecutively to produce fingerling of 9-12 $\mathrm{cm}$ length. However failure in fertilization process due to bad quality of broodstocks positioned them in difficult situation. Many of them are trapped in debt, although it doesn't stop them from actively striving. 
Out of many pressuring environmental situation, high fish mortality rate is the most undesirable situation. Farmers apply variety of techniques to control this situation, including utilization of herbs such as turmeric, or flooding the surface with kerosene to kill the pests such as ucitucit or Cybister larvae. Chemical pesticides are available in farm stores but mostly in a high price they can not afford.

Even after two decades of managing the system, there is no single formulation or technique to perform fresh water aquaculture management. People would say: "...experience is the best teacher...”, therefore individual experience strongly characterize people's attitude towards their environment when creating a habitat for cultured fishes. Such phenomenon occurs due to people's closeness to the system that is their main assets in their control. A true phenomenon found in Cameroon where small farmers are able to innovate due to their thorough understanding of the ecosystem (Jagoret et al, 2012), and also in Pasuruan East Java where locals show respect to their agricultural land by applying environmentally friendly management system (Mulyadi, 2011). A particular example regarding utilization of primary production means to improve effectively of aquaculture operation, is the use of fertilizer.

As commonly practiced in agricultural land preparation, soil in ponds also require nutrition enrichment. Four types of "fertilizers" used for different purposes i.e. chemical fertilizers (Nitrogen Phosphorus Kalium or NPK), organic fertilizer such as chicken manure, goat manure, salt and calcium. They do not have standardize application, quantity nor the type. Decision taken depends mainly on their own experience in taking care of their particular ponds. Thus, the management system is

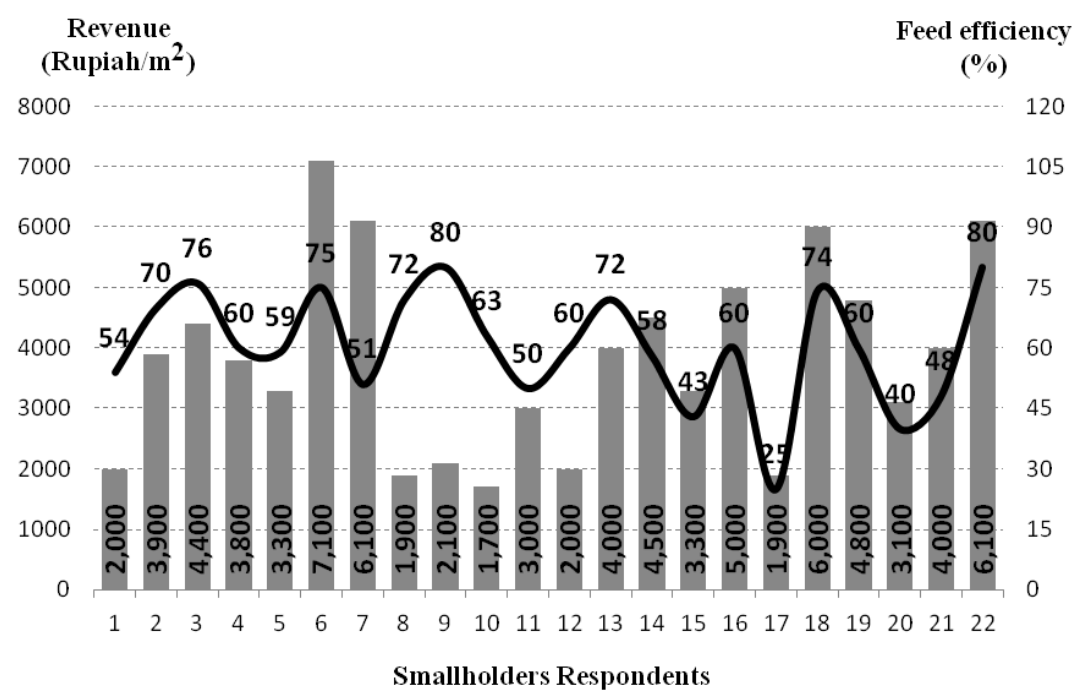

Figure 2. Fish pond revenue and feed efficiency of 22 smallholders in West Pagaden Subdistrict Subang Area. 
each other. We can see how varied their practices are, which just makes sense considering that they are applying them into the ecosystem under their own management. Regardless of positive or negative view of this condition, various understanding of aquaculture management reflected in different operational pattern applied by farmers is regarded as "variety of strategy" and the power of "self-confidence". But it can also be considered a "defensive" attitude, because they have no other choice than doing what must be done. Such "self belief" actually is a powerful indication of individual resilience that is potential to be transformed to become a community resilience with certain effort to institutionalize it (Pomeroy, 2011). However the next challenge should be to promote the principle of common property resource use. Marten (2001) emphasize the principle as important strategy to create commitment to the sustainable use of resource by agreeing that providing "opportunities for their children and grandchildren are as important as their own short-term gain”. This is highly relevant to the case of carp aquaculture in West Pagaden - Subang West Java, since the individual ponds are located in rice fields ecosystem. Perceived as one landscape, we can see a mosaic comprising of fish ponds and plots of rice fields in a irregular manner.

\section{Reorganize and Institutionalize the Learning and Adaptation}

Dealing with communities with diverse understanding of ecosystem management -in this case, freshwater fish ponds- requires special approach. Despite the uncertainty in local knowledge-based outcome of aquaculture, suspicion towards "new ideas" brought to them though based on result of research and development- will impede communication. The response of which is considered normal to insecure entity and small scale rural aquaculture farmers are. However, although many scholars consider small as vulnerable, D’Souza and Ikerd (1996) confirm that small farms have certain role in sustainable development for us not to ignore. This phenomenon is also found among farmers in Soppeng area acquiring the mind of sustainably managing their natural resources (Mulyadi, 2011).

In the case of small fish farmers in Subang area, promoting a community capacity-based model can be referred in preparing strategy of aquaculture community empowerment. The promotion of community capacity based model seems a very likely alternative since important prerequisite factors to develop environmentally friendly behavior are present in the case of small-scale fish farmers. Although still require more efforts to obtain better effectiveness, they also indicate capability of internal control and motivation to preserve local resources, two aspects required in developing the model (Mulyadi, 2011).

Technology information input should be provided and offered in the way that corresponds with the needs of the community, and it has to be done so because basically technology is a vehicle to change in culture (Lauer, 1989) so the benefit as well as risks must be very carefully considered. Despite many constraints, with a mission to attain sustainability, applying eco-aquaculture principle is possible because the communities are generally experienced in managing pond ecosystem. Ecological aquaculture has been defined as an alternative model of aquaculture research and development that brings the technical aspects of ecological principles and ecosystems thinking to aquaculture, and incorporates - at the outset principle of natural and social ecology, planning for community development, and concerns for the wider social, economic, and environmental context of aquaculture (White et al, 2004).In addition, provision of an incentive scheme to fish farmers who are successful in managing their ecosystem could be considered. Similar case is found in Pasuruan West Java, in which the main challenge is to establish strong "sense of belonging" of mangrove forest so that proposed socio-ecoregulation to effectively manage the ecosystem could be implemented (Muryani et al, 2011).

Still, "the more input, the higher productivity you will obtain" paradigm is found amidst aquaculture communities in Subang, while other parts of the world are shifting to sustainable alternatives. Should we keep aiming for productivity for the sake of current interest and sacrificing business sustainability? Should we let 1.1 millions family living on fishponds and managing Rp. 3,199 trillion worth of products work out their own difficulties? Aquaculture community's important role in attaining food security is acknowledged, not only locally but also globally, and the fact that most of the contributors are small medium sized farms (Lazard et al, 2010), focus towards establishing resilient fish farming community is imperative.

\section{CONCLUSION}

Socio-ecological resiliency of small-scale common carp (C. carpio) farmers are indicated by their adaptive strategy to cope with problems of availability of quality broodstock, water quantity and water quality, nutrient accumulation in soil and 
water, also the high price of feed. However, the confidence to move on due to their social and economical dependency on the aquaculture ecosystem should be considered a potency to further development.

In order to avoid the loss of resiliency, introducing the principle of common property resources is an appropriate strategy in relevance to the fact that there are two systems exist in one landscape, i.e. rice fields and fish ponds. Ecosystem management can be projected to achieve sustainable use of the natural resources. By implementing the strategy, we could retain a strong rural small aquaculture community making the achievement of sustainable economic activity becomes possible.

\section{ACKNOWLEDGEMENT}

Findings revealed in this paper is part of the research work conducted in 2011 on fish farmers community in Subang area which is supported by State Fund No 1.04.02 under Research Incentive Program of Food Security promoted by the Ministry of Research and Technology through the Centre of Appropriate Technology Development Indonesian Institute of Sciences. Special acknowledgement also dedicated to Fithria Novianti and Tita Irama for their approach to aquaculture farmers in villages has given rise to an understanding beyond figures.

\section{REFERENCES}

Anonymous, 2012. Subang in Numbers. Central Statistics Agency of Subang Region. Subang.

Anonymous, 2013. The Global Aquaculture Production Statistics for the Year 2011.FAO Fisheries and Aquaculture Department. Food and Agriculture Organization. Retrieved $8^{\text {th }}$ April 2014 from: http://www.fao.org/fi/ news/GlobalAquacultureProductionStatistics2 01.

Anonymous, 2014. FAO yearbook. Fishery and Aquaculture Statistics. Food and Agriculture Organization. Rome, 76 pp.

Anonymous, 2014 . Geographical Map of Subang District. Office of Public Works and Irrigation of Subang District. Subang.

Anonymous, $2014^{\mathrm{C}}$. Statistical Data on Marine and Fisheries. Ministry of Marine Affairs and Fisheries. Retrieved $4^{\text {th }}$ December 2014 from: http://statistik.kkp.go.id/index.php/statistik/c/1 2/0/0/0/0/Statistik-Perikanan-Budidaya-

Kolam/.
Carolina, 2010a. Environmental Feasibility of the Implementation of Freshwater Fish Culture Technology, in Carolina, Aji, H.A., and Novianti, F. (eds), Exploration of the Role of Appropriate Technology for Fish Farming Community. LIPI Press, Jakarta, pp 47-60.

Carolina, $2010^{\mathrm{b}}$. The Change of Agriculture Ecosystem, as A Consequence of the Development of Freshwater Fishponds in Subang Area, in Carolina, Aji, H.A. and Novianti, F.(eds), Evaluation on Sustainability of Freshwater Fish Aquaculture. LIPI Press, Jakarta. pp 11-23.

Carolina, and Aji H.S., 2008. Anticipation of Food Safety Decline as A Result of Intensification : Economic Feasibility Study of Fresh Water Common Carp Cultivation System in Subang. Proceedings of National Seminar on Food : Enhancement of Food Safety for Global Market, Yogyakarta, 17 Januari 2008.

D'Souza, G., and Ikerd, J., 1996. Small Farms and Sustainable Development : Is Small More Sustainable. Journal of Agriculture and Applied Economics, 28(1):73-83.

Folke, C., 2006. Resilience: The Emerging of Perspective for Social-Ecological Systems Analyses. Global Environmental Change, 16(3):253-67.

Hartono, T.T., and Nasution, Z., 2006. Status and Constraints of Carp Aquaculture Industry Development in Indonesia. Buletin Ekonomi Pertanian 5(2).

Jagoret P., Michel-Dounias, I., Snoeck, D., Ngnogue, H.T., and Malezieux, E., 2012. Afforestation of Savannah with Cocoa Agroforestry Systems: A Small-Farmer Innovation in Central Cameroon. Agroforestry System, 86(3):493-504.

Kittinger, J.N., Finkbeiner, E.M., Ban, N.C., Broad, K., Carr, M.H., Cinner, J.E., Gelcich, S., Cornwell, M.L., Koehn, J.Z., Basurt, X., Fujita, R., Caldwell, M.R., and Crowder, L.B., 2013. Emerging Frontiers in Social-Ecological System Research for Sustainability of Smallscale Fisheries. Current Opinion in Environmental Sustainability. Retrieved November $\quad 10^{\text {th }} \quad 2014 \quad$ from http://dx.doi.org/10.1016/j.cosust.2013.06.008.

Lauer, R.H., 1989. Perspective on Social Change. Cambridge University Press, Cambridge, pp 217-218.

Lazard, J., Baruthio, A., Mathe, S., Rey-Vallete, H., Chia, E., Clement, O., Aubin, J., Morissens, P., Mikolasek, O., Legendre, M., Levang, P., Blancheton, J. and Rene, F., 2010. Aquaculture System Diversity and Sustainable 
Development: Fish Farms and Their Representation. Aquaculture Living Resources, 23:187-198.

Marten, G.G., 2001. Human Ecology. Basic Concepts for Sustainable Development. Earthscan Publication Ltd., London, pp 53-71.

Mulyadi, 2011. The Effect of Local Wisdom, Locus of Control, and Motivation to Preserve the Environment towards the Environmentally Oriented Behavior of Farmers in Managing Agricultural Land in the District of Soppeng. Jurnal Manusia dan Lingkungan, 18(1):60-67.

Muryani, C., Ahmad, S.N., and Utami, T., 2011. Public Empowering Model in Maintaining and Conserving Mangrove Forest in Pasuruan Beach, East Java. Jurnal Manusia dan Lingkungan, 18(2):75-84.

Novianti, F., 2010. Local Knowledge on Fish Aquaculture, in Carolina, Aji, H.A., and Novianti, F. (eds), Evaluation on Sustainability of Freshwater Fish Aquaculture. LIPI Press, Jakarta, pp 39-60.

Pandjaitan, P., 2013. Evaluation on the Potential Contamination of Floating Cage Net PT Aquafarm Nusantara in the Toba Lake Ecosystem. Visi, 17(3):290-300.

Pomeroy, A., 2011. Rural Community Resilience and Climatic Change. Report to the Ministry of Agriculture and Forestry, New Zealand. Centre for Sustainability: Agriculture, Food, Energy, Environment. University of Otago, Dunedin, pp 61-63.
Rahmani, U., Syaukat, Y., Fauzi, A. and Hidayat, A., 2011. Internalization of Environmental Cost to Fish Culture in Cirata Dam Floating Cage Net System. Indonesian Journal of Agricultural Economics, 2(2):157-168.

Rasidi, and Prihadi, T.H., 2009. Phosphorus, Nitrogen and Hidrogen Sulfide Contents in Floating Cage Net Aquaculture Ecosystem in Cirata Reservoir West Java. Proceeding of Aquaculture Technology Innovation Forum. Research and Development Center of Marine and Fisheries, Jakarta.

Ratner, B.D. and Allison, E.H., 2012. Wealth, Rights, and Resilience : An Agenda for Governance Reform in Small-scale Fisheries. Development Policy Review, 30(4):371-398.

Riani, E., Sudarso, Y., and Cordova, M.R., 2014. Heavy Metal Effect on Unviable Larvae of Dicrotendipes simpsoni (Diptera: Chironomidae), A Case Study from Saguling Dam, Indonesia. Aquaculture, Aquarium, Conservation and Legislation. International Journal of Bioflux Society, 7(2):76-84.

Walker, B.H., Holling, C.S., Carpenter, S.R., and Kinzig, A., 2004. Resilience, Adaptibility and Transformation of Socio-Ecological Systems. Ecology and Society, 9(2):5.

White, K., O’Neill, B., and Tzankova, Z., 2004. At a Crossroads : Will Aquaculture Fulfill the Promise of the Blue Revolution. SeaWeb Aquaculture Clearinghouse. Retrieved April $1^{\text {st }}$ 2014 from: http:/www.seaweb.org/resources/ documents/reports_crossroads.pdf. 